\title{
SURVIVAL AND REPRODUCTION OF Podisus nigrispinus (HETEROPTERA: PENTATOMIDAE): EFFECTS OF PREY SCARCITY AND PLANT FEEDING
}

\author{
Anderson Mathias Holtz ${ }^{1}$, Gustavo Dias de Almeida ${ }^{2 *}$, Marcos Antonio Matiello Fadini, \\ José Salazar Zanuncio-Junior ${ }^{4}$, Teresinha Vinha Zanuncio ${ }^{4}$, and José Cola Zanuncio ${ }^{4}$
}

\begin{abstract}
The spined soldier bug Podisus nigrispinus (Dallas) (Heteroptera: Pentatomidae) is a generalist predator that can alternatively feed on plant tissue to survive under prey scarcity. This research aimed to evaluate the effects of plant feeding forced by a shortage of prey on the survival and reproduction of P. nigrispinus on Eucalyptus urophylla S.T. Blake (Myrtaceae) plants in the field. Podisus nigrispinus adults were enclosed on branches of eucalyptus by using gauze bags. These adults were fed daily with Tenebrio molitor pupae (T1) or after 5 (T2), 10 (T3) or 15 (T4) days from mating to simulate prey shortage. The pre-oviposition period, number of egg masses, number and viability of eggs and longevity of females were evaluated. Females of $P$. nigrispinus had a longer pre-oviposition period and produced lower number of egg masses as the period of prey shortage increased. However, the average number of eggs per egg mass, emergence of nymphs and longevity of $P$. nigrispinus females were not affected by prey shortage. Females of P. nigrispinus can survive 15 days without prey by feeding on eucalyptus leaves and if it finds prey afterwards can still reproduce. This shows that plant feeding is a successful incidental strategy to survive periods of food scarcity (and thus increase the efficiency) of this predator as a biological control agent.
\end{abstract}

Key words: Eucalyptus urophylla, phytophagy, biological control, predator, Asopinae.

\section{INTRODUCTION}

Predator releases in agriculture and forest systems represent a critical stage in biological control programs because adverse conditions including prey shortage can reduce their biological and reproductive potential (Westich and Hough-Goldstein, 2001; Fialho et al., 2009). However, some of these natural enemies can feed on plants as an alternative strategy what can, at least, partially compensate such situations (Zarpas et al., 2007).

Heteroptera are mainly sap sucking but some species of the Pentatomidae family developed predatory habits and they are common during insect outbreaks (Ferreira et al., 2008; Zanuncio et al., 2008). However, these stinkbug predators can feed on plant that also can benefit then

${ }^{1}$ Escola Agrotécnica Federal de Colatina/BR 259, 29709-910, Colatina, Espírito Santo, Brasil.

${ }^{2}$ Universidade Federal de Viçosa, Departamento de Fitotecnia, 36571-000, Viçosa, Minas Gerais, Brasil. *Corresponding author (gdalmeida.ufv@hotmail.com).

${ }^{3}$ Empresa de Pesquisa Agropecuária de Minas Gerais (Centro Tecnológico Zona da Mata), 36570-000, Viçosa, Minas Gerais, Brasil.

${ }^{4}$ Universidade Federal de Viçosa, Departamento de Biologia Animal, 36571-000, Viçosa, Minas Gerais, Brasil.

Received: 28 May2008.

Accepted: 06 october 2009.
(Azevedo et al., 2007; Guedes et al., 2007). Females of Brontocoris tabidus Signoret (Heteroptera: Pentatomidae) showed higher weight gain, oviposition rate, and longer longevity when Eucalyptus spp. plants were presented in addition to prey (Zanuncio et al., 2000; 2006a; 2006b). Supputius cincticeps (Stål) (Heteroptera: Pentatomidae) also had higher reproduction with prey and E. cloeziania than with prey only (Zanuncio et al., 2004).

The life cycle of predatory Pentatomidae depends on the amount and quality of the food ingested (Crum et al., 1998; Lemos et al., 2006). Depending on prey supply, these predators can reduce rate reproduction to maintain their survival within certain limits (Ramalho et al., 2008). Weight gain and food quality and quantity can affect instar duration, number of egg masses, besides egg viability and longevity of adults of these natural enemy (Zanuncio et al., 2002).

Prey shortage and plant feeding influence the insect life cycle and the predation efficiency of predatory Pentatomidae. Thus, the predator was induced to feed on E. urophylla, which is considered an alternative food source, during the prey scarcity. Hence, the objective of this research was to identify some costs and benefits of plant feeding towards its reproductive and survival consequences on the predator Podisus nigrispinus (Dallas) (Heteroptera: Pentatomidae). 


\section{MATERIAL AND METHODS}

The work was carried out at the Universidade Federal de Viçosa (UFV), Viçosa, Minas Gerais, Brazil. Average climatic conditions during the experiment (12 June to 19 September 2002), registered by the Department of Agricultural Engineering of the UFV, were temperature of $18.39 \pm 0.17{ }^{\circ} \mathrm{C}$, relative humidity of $75.01 \pm 0,73 \%$ and photophase of $11.20 \pm 0.39 \mathrm{~h}$.

First instar nymphs of $P$. nigrispinus were obtained from the Laboratory of Forest Entomology of the Department of Animal Biology of UFV and reared in groups of 10 per gauze bag $(30 \times 20 \mathrm{~cm})$ enclosing a branch of E. urophylla plants. These nymphs were fed with Tenebrio molitor L. (Coleoptera: Tenebrionidae) pupae until the adult stage (Zanuncio et al., 2004). Newly emerged adults were weighed on a scale with a precision of $0.1 \mathrm{mg}$ and separate by sexes according to the external appearance of their genitalia and body size. Ten $P$. nigrispinus pairs per treatment were formed on the second day after emergence and each pair was placed on a branch of eucalyptus after mating. The treatment was: T1: $P$. nigrispinus adults fed with $T$. molitor pupa every day, T2, T3 and T4: P. nigrispinus adults fed with T. molitor pupae every 5, 10 and 15 days after mating, respectively. Each treatment had by 10 replicates with a P. nigrispinus pair.

Pre-oviposition period, number of egg masses, eggs per mass and the survival of $P$. nigrispinus females were observed daily. Egg masses were removed from the gauze bags daily and placed in plastic Petri dishes $(9.0 \times 1.5 \mathrm{~cm})$ with a piece of cotton wool soaked with distilled water for humidity and kept in the laboratory $\left(25 \pm 2{ }^{\circ} \mathrm{C} ; 75 \pm 10\right.$ $\mathrm{RH}$ and $12: 12 \mathrm{~h}$ photoperiod) to obtain egg viability per female.

Preoviposition period, number of egg masses, number of eggs per egg mass and total longevity were transformed using $\log 10$ values. Eggs per egg mass and egg viability were transformed to arcsine. The values were submitted to ANOVA and the averages compared by Tukey test $(\mathrm{p}<$ $0.05)$.

\section{RESULTS}

The preoviposition period of $P$. nigrispinus increased with time of prey scarce. Females that did not suffer prey scarcity, show a preoviposition period of 10 days, those that had prey scarcity for 5,10 and 15 days, had this the period longer than 20 days (Figure 1A). However, the prey scarcity until 15 days did not reduce the number of eggs masses, eggs per mass and total eggs (Figures 1B, C, D and E). The longevity of $P$. nigrispinus females did not change with increasing period of prey scarcity (Figure 1F).

\section{DISCUSSION}

The negative effects of periods of prey scarcity shows that $P$. nigrispinus females delay their egg production with low food quality even with plant feeding in the field it demonstrates the necessity of frequent prey consumption to accumulate nutrients, with protein for reproduction (Legaspi and O'Neil, 1994).

Starvation periods on young P. nigrispinus females did not affect negatively the number of egg masses and the total number of eggs produced, but without reduction on the number of eggs per egg mass. This seems to be intrinsic to the species studied and it is not affected by adverse conditions including prey shortage, because oviposition would occur only after feeding on sufficient quantity and quality of prey to form egg masses (Shapiro et al., 2000; Wittmeyer et al., 2001). Similar egg viability between treatments shows that even with a cumulative effect of undernourishment or malnutrition, $P$. nigrispinus females did not reduce the egg viability if prey is found after 15 days of prey shortage.

The longevity of this predatory stinkbug was not affected by starvation periods. Then, we assume that plant feeding allows $P$. nigrispinus to survive during prey absence, increasing the probability of finding high quality food in the future. However, the improved survival renders the opportunity to resume reproduction when prey becomes available on a posterior stage. In addition, this predatory stinkbug can be capable of exploiting plants for its nutrients, increasing the plant feeding by prey scarcity (Gillespie and McGregor, 2000; Medeiros et al., 2004). Several authors have been reported for other heteropteran predators, such as Podisus rostralis (Stål) (Molina-Rugama et al., 1998) that feeding on plant material might be used only for survival whereas consumption of prey is needed for reproduction. Our findings show that $P$. nigrispinus presented a similar behavior. Thus, the facultative plant feeding by predators, called as zoophytophagy (Azevedo et al., 2007), needs more researches to understand the role of enzymes present in the salivary glands of this predator (Azevedo et al., 2003). Such information would contribute to understand the ecological and nutritional implications of the facultative phytophagy on foraging strategies shown by P. nigrispinus.

Predators compensate the food deficiency by reducing egg production. In natural conditions, this reduction will decrease the number of predators attacking the scarce prey and $P$. nigrispinus would not waste energy in searching for it. By minimizing the energetic costs, this predator would increase time for other activities such as plant feeding that would allow it to decrease water loss, oxygen consumption and metabolic rates (Wiedenmann 

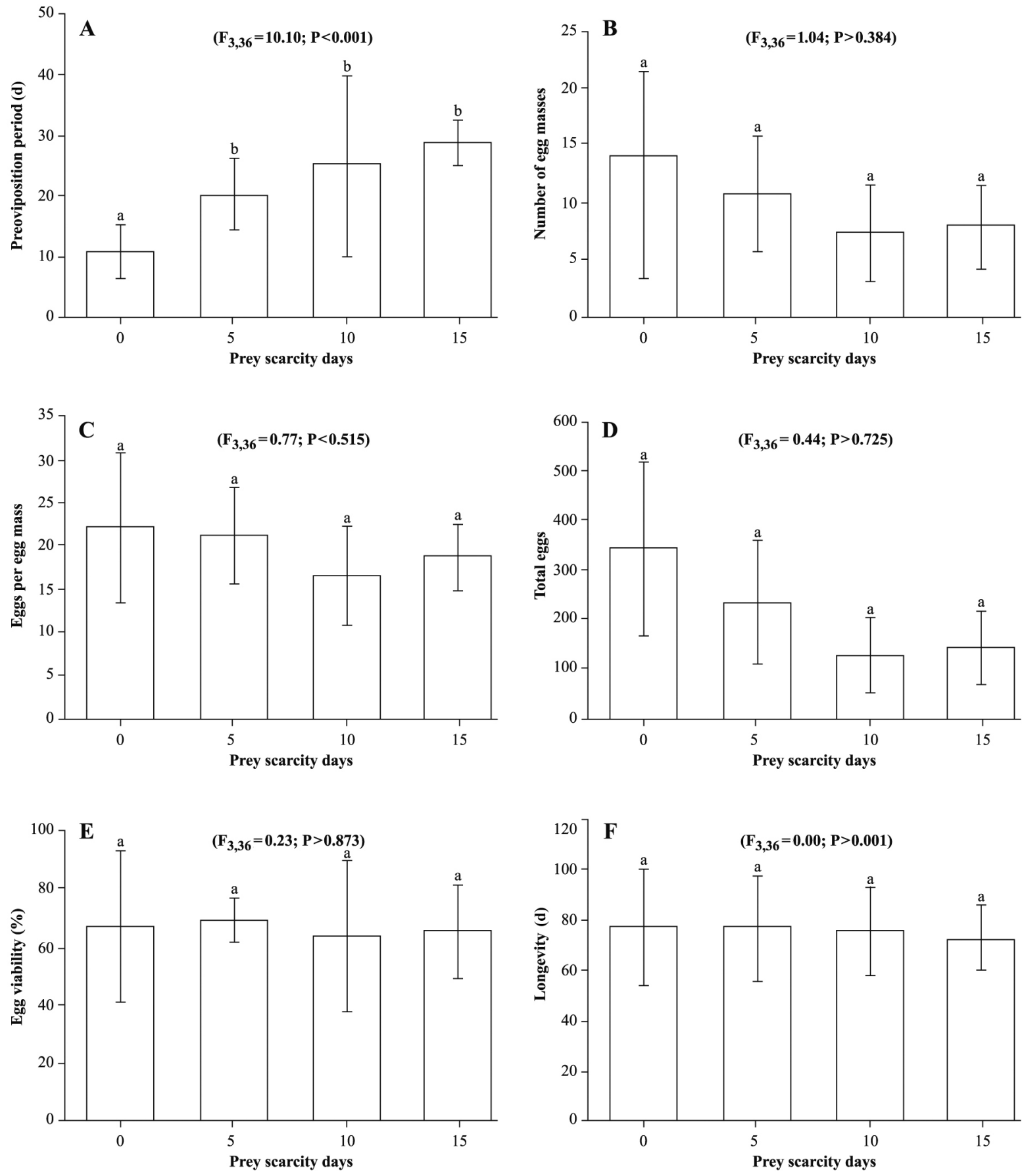

Figure 1. Effect of prey scarcity on biological parameters of Podisus nigrispinus (Heteroptera: Pentatomidae) on Eucalyptus urophylla. Means ( \pm standard deviation) followed by the same letters are not different according to the Tukey test $(\mathbf{p}>0.05)$.

and O'Neil, 1991). The generalist predators such as $P$. nigrispinus have better prey switching abilities without impairment of developmental and reproductive capacities and thus it is expected to have less difficulty subsisting under conditions of prey scarcity (Freitas et al., 2006).
Predatory stinkbugs have a set of adaptations to low attack rates, including trade-offs in survival and reproduction, feeding on plants to maintain body weight and using stored lipids to survive periods of low prey availability (Legaspi and O’Neil, 1994). 
Podisus nigrispinus females were able to maintain longevity but not their reproductive output under a food shortage what determines the importance of the herbivory in a trade-off between survival and reproduction. Lepidopteran defoliators are important in eucalyptus plantations (Zanuncio et al., 1993; 2006), and this adaptive behavior would explain why this predator is found in high populations at the end of caterpillar outbreaks and its ability to survive in these plantations when prey becomes scarce in the (Zanuncio et al., 2003). In this context, the trade-off between reproduction and survival buffers the population against food shortage or other factors that reduce reproduction. Therefore, understanding the nature of these adaptations we would be better able to use this predatory stinkbug in biological control or insect pest management programs.

\section{CONCLUSIONS}

The prey scarcity up to 15 days did not affect the reproductive capacity of the predator $P$. nigrispnus on plants of E. urophylla.

\section{ACKNOWLEDGEMENTS}

We thank the Conselho Nacional de Desenvolvimento Científico e Tecnológico (CNPq), Coordenação de Aperfeiçoamento de Pessoal de Nível Superior (CAPES) and Fundação de Amparo a Pesquisa do Estado de Minas Gerais (FAPEMIG) for financial support to the authors. We also thank T.V.M. Groot for his helpful discussion and comments on the manuscript.

\section{RESUMEN}

Supervivencia y reproducción de Podisus nigrispinus (Heteroptera: Pentatomidae): efectos de escasez de presas y alimentación vegetal. Podisus nigrispinus (Dallas) (Hetereptera: Pentatomidae) es un chinche depredador generalista que se alimenta alternativamente de tejidos vegetales para sobrevivir durante la época de escasez de sus presas. El objetivo de esta investigación fue evaluar los efectos de la alimentación forzada en condiciones de escasez de presa en la supervivencia y reproducción de $P$. nigrispinus en plantas de eucalipto Eucalyptus urophylla S.T. Blake (Myrtaceae) en campo. Adultos de P. nigrispinus fueron confinados en ramas de eucalipto usando bolsas de tela o gasa. Estos insectos fueron alimentados diariamente con pupas de Tenebrio molitor L. (Coleoptera: Tenebrionidae) (T1) o después de 5 (T2), 10 (T3) y 15 (T4) días después del cruzamiento para simular escasez de presa. Se evaluó el período de pre-oviposición, número de masas de huevos, número y viabilidad de huevos y longevidad de hembras. Hembras $P$. nigrispinus tuvieron un período de pre-oviposición más largo y menor producción de masas de huevos a medida que aumentó el período de escasez de presa, aunque el número promedio de huevos por masa, emergencia de ninfas y longevidad de hembras de $P$. nigrispinus no fue afectado por la escasez de presa. Las hembras de $P$. nigrispinus pueden sobrevivir y reproducirse hasta 15 días sin presa utilizando las hojas de eucalipto como fuente de alimento. El hábito de ser eventualmente fitófago es una estrategia muy bien aprovechada para la supervivencia de este depredador en períodos de escasez de presas, el cual puede aumentar la eficiencia de ese predador como agente de control biológico.

Palabras clave: Eucalyptus urophylla, fitofaga, control biológico, depredador, Asopinae.

\section{LITERATURE CITED}

Azevedo, D.D., J.E. Serrão, J.S. Jr. Zanuncio, G.F. Martins, J.C. Zanuncio, S. Marques-Silva, et al. 2003. Structure and protein pattern in the salivary gland of the obligate zoophytophage stinkbug Brontocoris tabidus (Heteroptera: Pentatomidae). Acta Microsc. 12:103-104.

Azevedo, D.D., J.C. Zanuncio, J.S. Jr. Zanuncio, G.F. Martins, S. Marques-Silva, M.F. Sossai, et al. 2007. Biochemical and morphological aspects of salivary glands of the predator Brontocoris tabidus (Heteroptera: Pentatomidae). Braz. Arch. Biol. Technol. 50:469-477.

Crum, D.A., L.A. Wieser, and N.E. Stamp. 1998. Effects of prey scarcity and plant material as a dietary supplement on an insect predator. Oikos 81:549-557.

Ferreira, J.A.M., J.C. Zanuncio, J.B. Torres, and A.J. Molina-Rugama. 2008. Predatory behaviour of Podisus nigrispinus (Heteroptera: Pentatomidae) on different densities of Anticarsia gemmatalis (Lepidoptera: Noctuidae) larvae. Biocontrol Sci. Techn. 18:711-719.

Fialho, M.D.C.Q., J.C. Zanuncio, C.A. Neves, F.S. Ramalho, and J.E. Serrão. 2009. Ultrastructure of the digestive cells in the midgut of the predator Brontocoris tabidus (Heteroptera: Pentatomidae) after different feeding periods on prey and plants. Ann. Entomol. Soc. Am. 102:119-127.

Freitas, S.P.C., W.S. Evangelista, J.C. Zanuncio, and J.E. Serrão. 2006. Development, survival and reproduction of Podisus nigrispinus (Dallas, 1851) (Heteroptera: Pentatomidae) with salt and amino acids solutions supplementary diet. Braz. Arch. Biol. Techn. 49:449455. 
Gillespie, D.R., and R.R. McGregor. 2000. The functions of plant feeding in the omnivorous predator Diciphus hesperus: water places limits on predation. Ecol. Entomol. 25:380-386.

Guedes, B.A.M., J.C. Zanuncio, F.S. Ramalho, and J.E. Serrão. 2007. Midgut morphology and enzymes of the obligate zoophytophagous stinkbug Brontocoris tabidus (Signoret, 1863) (Heteroptera: Pentatomidae). Pan.-Pac. Entomol. 83:66-74.

Legaspi, J.C., and R.J. O’Neil. 1994. Lipids and egg reproduction of Podisus maculiventris (Heteroptera: Pentatomidae) under low rates of predation. Environ. Entomol. 23:1254-1259.

Lemos, W.P., F.S. Ramalho, J.E. Serrão, J.C. Zanuncio, and E. Bauce. 2006. Diet affects reproduction and number of oocytes per ovary of the predator Podisus nigrispinus (Dallas) (Heteroptera: Pentatomidae). Anim. Biol. 56:279-287.

Medeiros, R.S.,A.M.C. Silva, J.C.Zanuncio, F.D. Ramalho, J.E. Serrão, and P.R. Cecon. 2004. Oviposition pattern of the predator Podisus nigrispinus (Heteroptera: Pentatomidae) under different temperatures. Biocontrol Sci. Techn. 14:487-498.

Molina-Rugama, A.J., J.C. Zanuncio, T.V. Zanuncio, and M.L.R. Oliveira. 1998. Reproductive strategy of Podisus rostralis (Stal) (Heteroptera: Pentatomidae) females under different feeding intervals. Biocontrol Sci. Technol. 8:583-588.

Ramalho, F.S., J. Mezzomo, W.P. Lemos, C.M. Bandeira, J.B. Malaquia, J.P.S. Silva, et al. 2008. Reproductive strategy of Podisus nigrispinus females under different feeding intervals. Phytoparasitica 36:30-37.

Shapiro, J.P., H.A. Wasserman, P.D. Greany, and J.L. Nation. 2000. Vitellin and vitellogenin in the soldier bug, Podisus maculiventris: identification with monoclonal antibodies and reproductive response to diet. Arc. Insect Biochem. Physiol. 44:130-135.

Westich, R., and J. Hough-Goldstein. 2001. Temperature and host plant effects on predatory stinkbugs for augmentative biological control. Biol. Control 21:160-167.

Wiedenmann, R.N., and R.J. O’Neil. 1991. Searching behavior and time budgets of the predator Podisus maculiventris. Entomol. Exp. Appl. 60:83-93.

Wittmeyer, J.L., T.A. Coudron, and T.S. Adams. 2001. Ovarian development, fertility and fecundity in Podisus maculiventris Say (Heteroptera: Pentatomidae): an analysis of the impact of nymphal, adult, male and female nutritional source on reproduction. Invertebr. Reprod. Dev. 39:9-20.
Zanuncio, J.C., J.B. Alves, G.P. Santos, and W.O. Campos. 1993. Monitoring and population-dynamics of lepidoptera associated with eucalyptus in BeloOriente region, Minas-Gerais, Brazil. Pesq. Agropec. Bras. 28:1121-1127.

Zanuncio, J.C., M.C. Lacerda, J.S. Jr. Zanuncio, T.V. Zanuncio, A.M.C. Silva, and M.C. Espindula. 2004. Fertility table and rate of population growth of the predator Supputius cincticeps (Heteroptera: Pentatomidae) in plants of Eucalyptus cloeziana in the field. An. Appl. Biol. 144:357-361.

Zanuncio, J.C., W.P. Lemos, M.C. Lacerda, T.V. Zanuncio, J.E. Serrão, and E. Bauce. 2006a. Age-dependent fecundity and fertility life tables of the predator Brontocoris tabidus (Heteroptera: Pentatomidae) under field conditions. J. Econ. Entomol. 99:401-407.

Zanuncio, J.C., A.J. Molina-Rugama, G.P. Santos, and F.S. Ramalho. 2002. Effect of body weight on fecundity and longevity of the stinkbug predator Podisus rostralis. Pesq. Agropec. Bras. 37:1225-1230.

Zanuncio JC, Silva, E.R. Lima, F.F. Pereira, F.D. Ramalho, and J.E. Serrão. 2008. Predation rate of Spodoptera frugiperda (Lepidoptera: Noctuidae) larvae with and without defense by Podisus nigrispinus (Heteroptera: Pentatomidae). Braz. Arch. Biol. Technol. 51:121-125.

Zanuncio, J.C., T.V. Zanuncio, F.A. Freitas, and D. Pratissoli. 2003. Population density of Lepidoptera in a plantation of Eucalyptus urophylla in the state of Minas Gerais, Brazil. Anim. Biol. 53:17-26.

Zanuncio, T.V., J.C. Zanuncio, F.A. Freitas, D. Pratissoli, C.A.Z. Sediyama, and V.P. Maffia. 2006b. Main lepidopteran pest species from an eucalyptus plantation in Minas Gerais, Brazil. Rev. Bio. Trop. 54:553-560.

Zanuncio, J.C., T.V. Zanuncio, R.N.C. Guedes, and F.S. Ramalho. 2000. Effect of feeding on three Eucalyptus species on the development of Brontocoris tabidus (Heteroptera: Pentatomidae) fed with Tenebrio molitor (Coleoptera: Tenebrionidae). Bioc. Sci. Technol. 10:443-450.

Zarpas, K.D., J.T. Margaritopoulos, and J.A.Tsitsipis. 2007. Life histories of generalist predatory species, control agents of the cotton aphid Aphis gossypii (Hemiptera: Aphididae). Entomol. Gen. 30:85-101. 